\title{
SUPPLEMENT TO THE PHYTOGEOGRAPHICAL STUDIES OF THE RARE AND INTERNATIONALLY SIGNIFICANT SPECIES IN THE FLORA OF SERBIA, KOSOVO AND METOHIJA NORTH
}

\author{
DANIJELA PRODANOVIĆ ${ }^{{ }^{*}}$, ZORAN KRIVOŠEJ ${ }^{2}$, MILOŠ STANOJEVIĆ ${ }^{2}$, SLAVICA \\ ĆIRIĆ 1
}

${ }^{1}$ Faculty of Agriculture, University of Priština, Lešak, Serbia

${ }^{2}$ Faculty of Natural Science and Mathematics, University of Priština, Kosovska Mitrovica, Serbia

\begin{abstract}
This paper reports the chorological data on 3 internationally significant floristic species in Serbia, in the Ibar river valley, Kosovo and Metohija North. Those are: Gladiolus palustris Gaudin, Himantoglossum caprinum (M. Bieb) Spreng. and Narcissus poeticus subsp. radiiflorus (Salisb.) Baker. It also reports new research findings on a rare species of vascular flora of Serbia - Phlomoides tuberosa $(\mathbf{L}$.) Moench. The distribution of the mentioned species is shown in UTM $10 \mathrm{~km} \mathrm{X} 10 \mathrm{~km}$ squares, based on the field researches, herbarium collections inspections and literature data. As the studied species belong to the group of internationally important and rare species, the familiarity with the status of their populations and degree of their vulnerability would present a good basis for monitoring their protection both in Serbia and Europe.
\end{abstract}

Keywords: Flora of Serbia, Internationally significant species, Rare species, Ibar river valley, Phytogeographical study.

\section{INTRODUCTION}

The Republic of Serbia covers only $1.9 \%$ of the whole of the European territory. This area is inhabited by 3662 taxa of vascular plants, classified as species and subspecies (Stevanović et al., 1995) and they present approximately $18 \%$ of vascular European flora (Mijović et al., 2012). Serbia is a country of rich ecosystem and species diversity. The diversity of ecosystems in Serbia is primarily evident in the diversity and specific character of its vegetation (IUCN, 2017). Endemic plant species give a special contribution to the floristic abundance of the Republic of Serbia because 547 Balkan endemic taxa were reported on its territory (Tomović, 2007). Out of total number of floral species in the Republic of Serbia, 1128 vascular species are protected by national legislation and 161 species belong to the group of internationally significant floral species (Stojanović et al., 2015).

In terms of biodiversity conservation, refugial areas (high mountainous regions, salt marshes, canyons and gorges) have a special significance. Thus the Ibar river gorge, Kosovo and Metohija North, with the serepentine mountains encircling it, presents an important region of the floristic diversity, endemism in our country, rare species and the species that are subjected to different categories of protection in international legislations (IUCN, The Berne Convention, CITES etc.).

The largest serpentine areas in Europe are in the Balkan peninsula. In Serbia there are several serpentine zones located primarily in central, western and south-western Serbia and in Kosovo and Metohija (Jakovljević et al., 2011). On the territory

\footnotetext{
* Corresponding author: danijela.prodanovic@pr.ac.rs
} BIOLOGY of Kosovo and Metohija the largest complexes are found in the valley of the Ibar river, and the same are continued in a discontinuous chain through Koznica and Goleš, to the southwest.

All types of floristic field studies have been continuously conducted in these areas in the middle course of the Ibar, Kosovo and Metohija`s Far North since 2002. Hitherto researches on the serpentines in the Kosovo part of the Ibar gorge have reported around 950 taxa and they represent more than $25 \%$ of total flora of Serbia. The result of these researches have revealed totally new and hitherto unknown chorological data on some internationally significant and endemic plant species, as well as on the species rarely present in the flora of Serbia.

\section{EXPERIMENTAL}

Materials and methods

On the basis of the material collected during the field work (from 2008-2017), on the serpentines of the Ibar river valley in Kosovo's part, we present study for four mentioned vascular plants.

Identification of the collected plant material is made according to Flora of Serbia (Josifović 1974, 1975, 1976; Sarić 1986) and Flora Europae (Tutin et al., 1972, 1980); the nomenclature was adjusted to The Plant List (2013).

Besides the field survey, checking of herbarium material and relevant literature sources were used to present an overall distribution for studied taxa in Serbia. The given taxa are mapped on $10 \times 10 \mathrm{sq} \mathrm{km}$ at UTM grid system (UTM Zone 34T) (Lampinen, 2001). 
The threats that potentially jeopardize the survival of the species have been recognized and the measures to protect them have been recommended.

\section{RESULTS AND DISCUSSION}

Fam.: IRIDACEAE

Gladiolus palustris Gaud.

General distribution: middle and southern Europe. North of the Alps, it ranges from eastern France and the Alsace, Germany, Czech Republic, Slovakia, Poland eastwards with fragmented patches in Belarus, Ukraine and Russia. South of the Alps, it extends from the Appenines in Italy to eastern Austria and Hungary where it extends to western Bulgaria and Albania in the Balkans (Bilz, 2011).

Distribution in Serbia: Grdelička klisura, Kosanica, Luka below Stol mountain, Studena mt., Pešterska Highlands, Podvrška, Veliki Deli Jovan, Ušće; Kosovo and MetohijaBrezovica, Jezerska planina, Koritnik, Koznik, Kodža Balkan, Popovica, Radipolje, Tumba (Stojanović et al., 2015); Ibar river valley, from Brnjak to Kosovska Mitrovica (TomićStanković,1967).

New chorological data in Serbia (Figure 1): village Bube (Ibarski Kolašin), meadow near the road: $42^{0} 59$ ' 39, “ N, $20^{0} 48$ 07,9“E (925 m a.s.1) UTM 34 TDN74 (leg./det. Krivošej, Z.\& Prodanović, D., 19-June-2008); village Bube, meadow near the school: $42^{0} 58^{\prime} 67,9^{\prime \prime} \mathrm{N}, 20^{\circ} 37^{\prime} 33,2^{\prime \prime} \mathrm{E}$ (972 m a.s.l) UTM 34 TDN74 (leg./det. Krivošej, Z.\& Prodanović, D., 01-June-2008); village Dren, near Mokra Gora Moutain: $42^{0} 51^{\prime} 88,0^{\prime \prime} \mathrm{N}, 20^{0} 38^{\prime}$ 55.7“E (1004 m a.s.l) UTM 34 TDN65 (leg./det. Krivošej, Z.\& Prodanović, D., 30-July-2008)

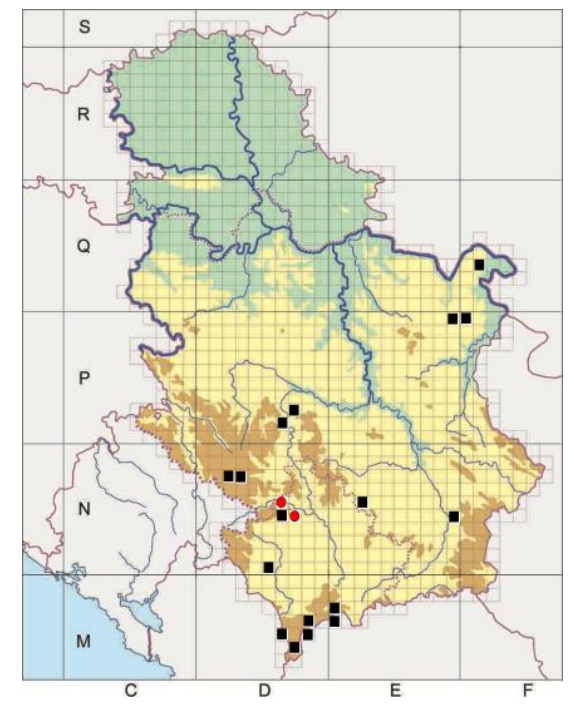

Figure 1. Distribution of the species Gladiolus palustris Gaud. in Serbia. New records marked with red circle.

Species Gladiolus palustris is a European endemic. It prefers periodically wet meadows but is tolerant to dryness. If the habitat is not periodically wet the populations decrease due to competition from other plants (Käsermann \& Moser, 1999).

Even though the literature data (Tomić-Stanković, 1967) on the presence of species in Ibarski Kolašin, from Brnjak to Kosovska Mitrovica, existed, it was not included in the 1976 edition of The Flora of Serbia (Josifović). This may have been caused by the extinction of the natural habitats due to the construction of the artificial Gazivode lake (1973-1977), which completely jeopardized the survival of species. The 2010 field checkout did not find species in the Brnjak village area nor in the lower course of the river towards Kosovska Mitrovica.

This internationally important floral species was identified on the wet meadows in the vicinity of the village of Bube, Ibarski Kolašin. It grows, along with a rather rare fern species Ophioglossum vulgatum L., on the wet meadow above the school (Table 1).

Table 1. Phytocenologic recording for species Gladiolus palustris Gaud.

\begin{tabular}{|c|c|}
\hline Locality & Ibarski Kolašin-village Bube \\
\hline GPS & $42^{0} 58^{\prime} \quad 67,9^{\prime \prime} \mathrm{N} 20^{\circ} 37^{\prime} 33,2^{\prime \prime} \mathrm{E}$ \\
\hline Size of the sampled area $(\mathrm{P})$ & $400 \mathrm{~m}^{2}$ \\
\hline Date & 01.06 .2008 . \\
\hline Altitude (m) & 925 \\
\hline Exposition & SW \\
\hline Slope & $40^{\circ}$ \\
\hline Geological substratum & siliceous soil \\
\hline Gladiolus palustris Gaud. & 3.3 \\
\hline Ophioglossum vulgatum L. & 3.3 \\
\hline Filipendula vulgaris Moench. & 3.3 \\
\hline Trifolium incarnatum L. & 2.2 \\
\hline Genista sagittalis L. & 2.2 \\
\hline Lathyrus pratensis L. & 2.2 \\
\hline Vicia cracca $\mathrm{L}$. & 2.2 \\
\hline Cynosurus cristatus L. & 2.2 \\
\hline Festuca sp. & 1.2 \\
\hline Anthoxanthum odoratum L. & 1.2 \\
\hline Briza media L. & 1.2 \\
\hline Oenanthe silaifolia $\mathrm{M}$. & 1.1 \\
\hline Bieb. & \\
\hline Moenchia mantica (L.) & 1.1 \\
\hline Bartl. & \\
\hline Galium verum $\mathrm{L}$. & 1.1 \\
\hline Dianthus deltoides L. & 1.1 \\
\hline Plantago media $\mathrm{L}$. & 1.1 \\
\hline Anacamptis morio (L.) & 1.1 \\
\hline $\begin{array}{l}\text { R.M.Bateman, Pridgeon \& } \\
\text { M.W.Chase }\end{array}$ & \\
\hline Trifolium patens Schreb. & 1.1 \\
\hline Trifolium montanum L. & 1.1 \\
\hline $\begin{array}{l}\text { Danthonia calycina Roem } \\
\text { \&Schult. }\end{array}$ & 1.1 \\
\hline Hypochaeris maculata $\mathrm{L}$. & 1.1 \\
\hline Rumex acetosa $\mathrm{L}$ & 1.1 \\
\hline Alopecurus pratensis L. & 1.1 \\
\hline Dianthus carthusianorum L. & 1.1 \\
\hline Neotinea ustulata (L.) & + \\
\hline $\begin{array}{l}\text { R.M.Bateman, Pridgeon } \quad \& \\
\text { M.W. Chase }\end{array}$ & \\
\hline Trifolium pratense L. & + \\
\hline
\end{tabular}


In another locality, a meadow which lies under a mixed oak tree wood keeps water and humidity in its lower part for the greater part of the year creating favourable conditions for the growth of marsh gladiolus. The mentioned localities boast a considerable number of individuals. There are several hundred individuals in each locality. The species was discovered in the vicinity of the village of Dren, at the foot of Mokra Gora mountain at later phenological stage, when the capsules were formed, so it was slightly difficult to estimate its number (approximately a hundred individuals).

Since these areas are sparsely populated, they are not constantly threatened by man, although the cattle are periodically taken out to pastures. Cutting grass may also present a threat to the gladiolus population. Another real manace would be its overexploatation due to its decorative feature. Nevertheless, it is still not considered an acute anthropogenic activity. A considerable decrease in number of species and the species extinction are reported in the European continent. The species is protected in Serbia by The Habitats Directive, Bern Convention, by the Law on Nature Protection and the Law on Trade in Endangered and Protected Species of Wild Flora and Fauna.

Fam.: ORCHIDACEAE

Himantoglossum caprinum (M. Bieb.) Spreng.

General distribution: southeastern Europe and Middle East.

Distribution in Serbia: Vojvodina-Fruška gora; Serbia: Đavolja varoš, Đerdap, Đetinja, Jadovnik, Jelašnička George, Svrljiški Timok George, Jerma George, Mileševka George, Ozren, Mokra gora, Pešter highland, Sićevačka George, Suva mt., Zaovine, Zlatibor, Zlotska George; Kosovo and MetohijaGrmija, near by Priština, canyon of Miruša, Prokletije, Šarplanina (mt.) (Stojanović et al., 2015).

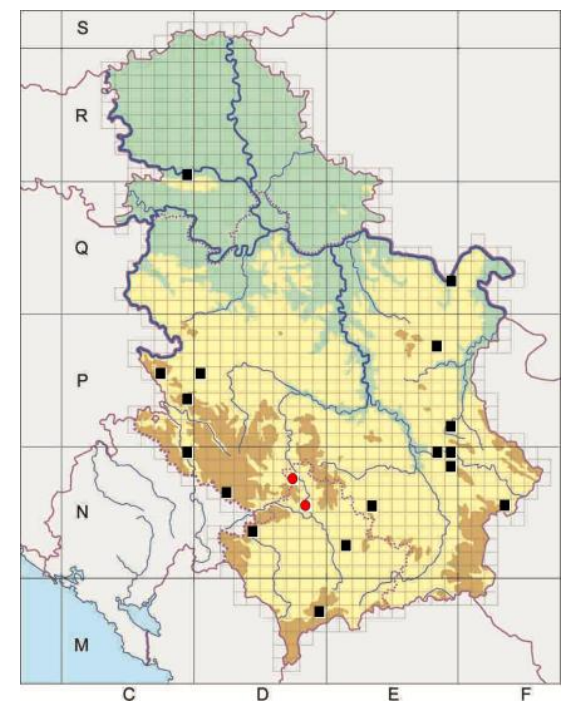

Figure 2. Distribution of the species Himantoglossum caprinum (M.Bieb.) Spreng. in Serbia. New records marked with red circle.

New chorological data in Serbia (Figure 2): villages Žitkovac-Valač (near Kosovska Mitrovica town): $42^{0} 56^{\prime} 77,9^{“ ”} \mathrm{~N}$,
$20^{0} 49^{\prime}$ 50,6“" E (579 m a.s.1) UTM 34 TDN85 (leg./det. Krivošej, Z.\& Prodanović, D., 14-June-2010); $42^{0} 36^{\prime} 33,8^{\prime \prime}$ N, $21^{0} 12^{\prime} 97,5^{\prime \prime}$ E (544 m a.s.l) UTM 34 TDN85 (leg./det. Krivošej, Z.\& Prodanović, D., 14-June-2010; village Vračevo (Ibar river valley) $43^{\circ} 10^{\prime} 93,3^{\prime \prime} \mathrm{N}, 20^{\circ} 40^{\prime} 47.4^{\prime \prime} \mathrm{E}$ (473 m a.s.1) UTM 34 TDN77 (leg./det. Krivošej, Z.\& Prodanović, D., 08-July-2011).

Himantoglossum caprinum grows in poor grassland, woodland edges, forest-steppes, and open woodland such as oak groves (Rankou, 2011). It prefers dry and calcareous soils.

This perennial orchid in newly-discovered localities in Valač (Table 2) and Vračevo village areas, grows as solitary individuals in very small groups, but is easily remarkable due to its imposing size and beauty.

Although it is cited in the Flora of Serbia (Josifović, 1976) and recent literature (Rankou, 2011; Stojanovic et al., 2015) that it grows in habitats with limestone background, the existance of this species on the serpentines of the Ibar gorge proves that other types of soil (composed predominantly of silica) can also host it.

Table 2. Phytocenologic recording for species Himantoglossum caprinum (M. Bieb.) Spreng.

\begin{tabular}{|c|c|}
\hline Locality & Village Žitkovac-Valač \\
\hline GPS & $42^{0} 56^{\prime} 77,9^{\prime \prime} \mathrm{N}, 20^{0} 49^{\prime} 50,6^{\prime \prime} \mathrm{E}$ \\
\hline Size of the sampled area $(\mathrm{P})$ & $20 \mathrm{~m}^{2}$ \\
\hline Date & 14.06.2010. \\
\hline Altitude (m) & 579 \\
\hline Exposition & $\mathrm{W}$ \\
\hline Slope & $10^{0}$ \\
\hline Geological substratum & siliceous rocky ground \\
\hline Quercus cerris $\mathrm{L}$. & + \\
\hline Quercus frainetto Ten. & + \\
\hline $\begin{array}{l}\text { Himantoglossum caprinum } \\
\text { (M.Bieb.) Spreng }\end{array}$ & $\mathrm{r}$ \\
\hline Lotus corniculatus $\mathrm{L}$. & 1.1 \\
\hline $\begin{array}{l}\text { Petrorhagia saxifraga (L) } \\
\text { Link. }\end{array}$ & 1.1 \\
\hline Lathyrus niger (L.) Bernh. & 1.1 \\
\hline Achillea millefolium $\mathrm{L}$. & + \\
\hline Digitalis lanata Ehrh. & + \\
\hline Trifolium alpestre $\mathrm{L}$. & + \\
\hline Astragalus glycyphyllos L. & + \\
\hline $\begin{array}{l}\text { Helleborus odorus Waldst. \& } \\
\text { Kit. ex Willd. }\end{array}$ & $\mathrm{r}$ \\
\hline Prunus spinosa L. & $\mathrm{r}$ \\
\hline
\end{tabular}

Species Himantoglossum carpinum has unresolved taxonomic status and then existence of this taxon in the territory of Serbia is questioned. According to Molnár et al., (2012) the name $H$. caprinum has been consistently and correctly applied to Crimean lizard orchid, which does not actually occur to central European territories. The name $H$. caprinum, which was misused for this species, was replaced with $H$. jankae Somlyay, Kreutz \& Óvári. A new name, Himantoglossum jankae, is given to the widely recognised lizard orchid species that is distributed primarily in Slovakia, Hungary, Romania, Croatia, Serbia, Montenegro, Macedonia, Albania, Bulgaria, Greece, northern Turkey. Molnár et al., (2012) for the territory of Serbia cite subsp. caprinum near Vršac; by their opinion it's $H$. jankae. The 
recent data in the check list (WCSP, 2017) present as accepted taxonomic name for this species Himantoglossum caprinum subsp. jankae (Somlyay, Kreutz \& Óvári) R.M. Bateman, Molnar \& Sramkó, Peerj 5 (e2893):69 (2016). We think that a taxonomic revision of the data taken from the literature should include verification of herbarium material in future work (It is necessary to clarify the taxonomic status of the subspecies by checking the herbarium material to determine exactly where the species referred to as caprinum is growing in Serbia). Also, our phytogeographical supplement should be taken into account.

The species is strictly protected under the name of Himantoglossum hircinum (L.) Spreng. by the Law on Trade in Endangered and Protected Species of Wild Flora and Fauna as well by International Conventions-Bern Convention and CITES.

Removal from the habitat by woody invasive plants, afforestation, soil erosion and accumulation present a threat to the species (Stojanović et al., 2015). In two newly- discovered localities in the Ibar valley, Kosovo and Metohija North, pastures on the edges of the forests and plant gathering due to its decorative features were identified as potential dangers.

Fam. AMARYLLIDACEAE

Narcissus poeticus subsp. radiiflorus (Salisb.) Baker (syn. Narcissus angustifolius G.Don).

The Narcissus genus comprises 20-40 species (The Flora of Serbia) or over 140 species (The Plant List, 2013), mostly distributed in the Mediterranean and in Middle and East Asia. Only one species grows indigenously in the Flora of Serbia.

General distribution: southern and east-central Europe (Alps, Carpatians), extends to the Ukraine, former Yugoslav republics, northern Greece (Chadburn, 2014).

Distribution in Serbia: Divčibare, Đetinja, Maljen, Ozren, Preševo (Miratovac), Stolovi (Svračak), Studena mountain (Kraljevo), Tara, Uvac, Zlatibor, Kopaonik (probably extinct, by Stojanović et al., 2105). Our observations shows that the species is growing on the slopes of the Kopaonik, near the Jošanička banja ; Kosovo and Metohija: Drenica, Glogovac (Dobroševac), Podujevo, Priština, Šar-planina/mountain, Uroševac.

New chorological data in Serbia (Figure 3): village Rudine (Rogozna mountain): $43^{0} 01^{\prime} 260^{\prime \prime} \mathrm{N}, 20^{\circ} 45^{\prime} 153^{\prime \prime} \mathrm{E}$ (910 m a.s.l) UTM 34 TDN76 (leg./det. Krivošej, Z.\& Prodanović, D., 12May-2012); $43^{0} 01^{\prime} 387^{\prime \prime} \mathrm{N}, 20^{0} 45^{\prime} 307^{\prime \prime} \mathrm{E}$ (895 m a.s.l) UTM 34 TDN76 (leg./det. Krivošej, Z.\& Prodanović, D., 12-May-2012).

During the 2012 field researches on Rogozna Mt., Kosovo and Metohija North, this perennial plant or geophyte was identified in two relatively close localities. In both localities, the species inhabits wet meadows with mountainous streams running through it. From the beginning of summer season they are filled with water and then they become dry in the hottest part of the year. In both localities their number is exceptionally large and is estimated from several hundred to a thousand individuals, so the localities become real narcissus fields at the blooming season in May.
Floristic composition can be best observed from the following phytocenologic recording (Table 3).

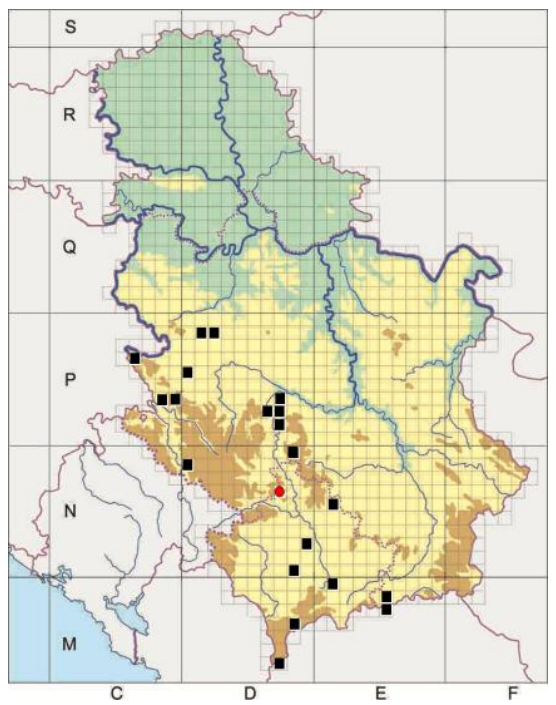

Figure 3. Distribution of the species Narcissus poeticus subsp. radiiflorus (Salisb.) Baker in Serbia. New record marked with red circle.

Table 3. Phytocenologic recording for species Narcissus poeticus subsp. radiiflorus (Salisb.) Baker

\begin{tabular}{|c|c|}
\hline Locality & Rogozna Mountain-Rudine village \\
\hline GPS & $43^{\circ} 01^{\prime} 260^{\prime \prime} \mathrm{N}, 20^{\circ} 45^{\prime} 153^{\prime \prime} \mathrm{E}$ \\
\hline Size of the sampled area $(\mathrm{P})$ & $400 \mathrm{~m}^{2}$ \\
\hline Date & 12.05.2012. \\
\hline Altitude(m) & 910 \\
\hline Exposition & $\mathrm{N}$ \\
\hline Slope & $40^{\circ}$ \\
\hline Geological substratum & siliceous ground \\
\hline $\begin{array}{l}\text { Narcissus poeticus subsp. } \\
\text { radiiflorus (Salisb.) Baker }\end{array}$ & 4.4 \\
\hline Thalictrum minus $\mathrm{L}$. & 2.2 \\
\hline Filipendula vulgaris Moench & 2.2 \\
\hline Ranunculus acris L. & 2.2 \\
\hline Pedicularis palustris $\mathrm{L}$. & 1.2 \\
\hline $\begin{array}{l}\text { Eleocharis palustris (L.) } \\
\text { Roem. \& Schult. }\end{array}$ & 1.2 \\
\hline Oenanthe silaifolia M.Bieb & 1.1 \\
\hline Galium verum $\mathrm{L}$ & 1.1 \\
\hline Rumex acetosa $\mathrm{L}$. & 1.1 \\
\hline Lathyrus pratensis $\mathrm{L}$. & 1.1 \\
\hline Ajuga genevensis $\mathrm{L}$ & 1.1 \\
\hline Veronica austriaca $\mathrm{L}$ & + \\
\hline $\begin{array}{l}\text { Mercurialis ovata Sternb.\& } \\
\text { Hoppe }\end{array}$ & + \\
\hline Plantago argentea Chaix & + \\
\hline $\begin{array}{l}\text { Anacamptis morio (L.) R.M. } \\
\text { Bateman, Pridgeon \& M.W. } \\
\text { Chase M.W }\end{array}$ & + \\
\hline Polygala comosa Schkuhr & + \\
\hline $\begin{array}{l}\text { Potentilla erecta (L.) } \\
\text { Raeusch. }\end{array}$ & + \\
\hline Carex filiformis $\mathrm{L}$. & + \\
\hline Sanguisorba officinalis L & + \\
\hline $\begin{array}{l}\text { Quercus petraea (Matt.) } \\
\text { Liebl }\end{array}$ & $\mathrm{r}$ \\
\hline
\end{tabular}


Since the newly - discovered localities are far away from the settlements and thoroughfares, it is assumed that there is no real danger for the narcissus population caused by anthropogenic activity. First of all, it refers to the sponataneous plant gathering due to its decorative features, which is a common and frequent case in other localities in Serbia. Likewise, cattle grazing should not present a real danger at the moment as the cattle (sheep and cows were noticed during the field researches) avoid eating narcissus because of its toxic ingredients in all parts of the plant.

Fam. LAMIACEAE

Phlomoides tuberosa (L.) Moench.

General distribution: from Siberia to Caucasus, northern Iraqi and Asia, through middle and southern part of Russia, along Danube river to Hungary.

Distribution in Serbia: Lešje (Ćuprija), Pirkovac, Niševci (Knjaževac), Blace; Kosovo: okolina Srbice.

New chorological data in Serbia (Figure 4): village Ibarska Slatina (Ibar river valley): $43^{0} 02^{\prime} 85.4^{\prime \prime} \mathrm{N}, 20^{\circ} 49^{\prime} 0,30^{\prime \prime} \mathrm{E}$ (451 m a.s.l) UTM 34 TDN87 (leg./det. Krivošej, Z., Prodanović, D.\& Stanojević, M. 15-June-2017).

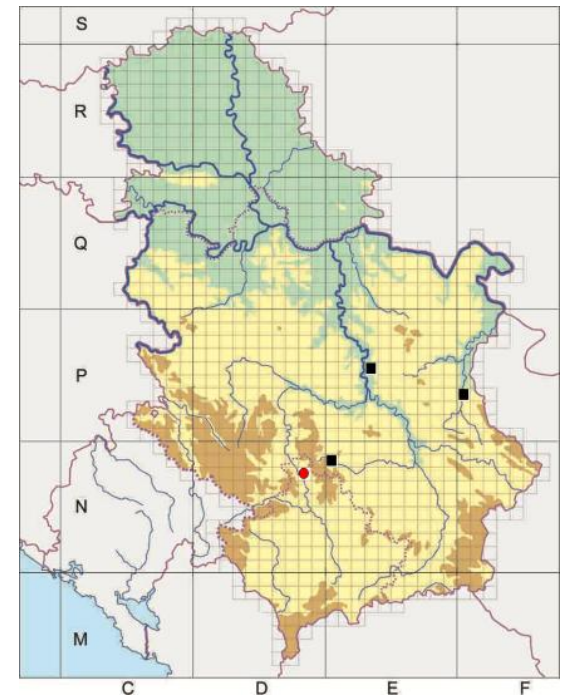

Figure 4. Distribution of the species Phlomoides tuberosa (L.) Moench. in Serbia. New record marked with red circle.

The genus Phlomoides Moench with about 150-170 species belongs to Lamiaceae, subfamily Lamioideae, tribe Phlomideae (Salmaki \& Yonarchi, 2014). The distribution area of the genus extends from central Europe to the Russian Far East. The major centers of diversity of Phlomoides are Central Asia, the Iranian highlands, including Afghanistan, Iran, W Pakistan, SW Turkmenistan, and China, but includes a few species extending to Mediterranean Europe (Salmaki et al., 2012).

The Flora of Serbia describes only one species as Phlomoides genus (described as Phlomis in old classification), Ph. tuberosa. In June 2017, we conducted field researches on the serpentines of the Ibar valley, in close proximity to Kosovska Mitrovica- Kraljevo highway, on the right bank of the Ibar, in
Ibarska Slatina area. (Figure 5). We came across a new locality in Kosovo and Metohija with this rather rare steppe relict species (Stevanović, 1999) in the flora of Serbia. It is the second presently known locality in Kosovo and Metohija territory. Although the Flora of Serbia (1974) mentions the presence of the species in eastern Serbia, recent researches do not corroborate this data (Bogosavljević et al., 2007).

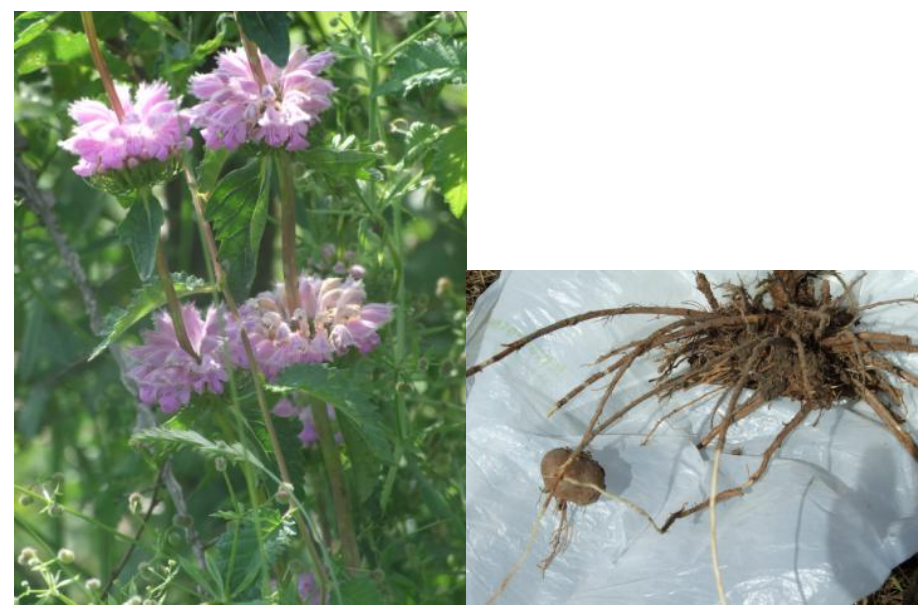

Figure 5. Phlomoides tuberosa (L.) Moench. in Ibarska Slatina locality (photo. D. Prodanović).

The floristic structure in the Ibarska Slatina locality can be seen from next phytocenological record (Table 4).

Table 4. Phytocenologic recording for species Phlomoides tuberosa (L.) Moench.

\begin{tabular}{|c|c|}
\hline Locality & Village Ibarska Slatina \\
\hline GPS & $43^{0} 02^{\prime} 85.4^{\prime \prime} \mathrm{N}, 20^{\circ} 49^{\prime} 0,30^{\prime \prime} \mathrm{E}$ \\
\hline Size of the sampled area $(\mathrm{P})$ & $30 \mathrm{~m}^{2}$ \\
\hline Date & 15.07.2017. \\
\hline Altitude (m) & 451 \\
\hline Exposition & $\mathrm{NE}$ \\
\hline Slope & $30^{0}$ \\
\hline Geological substratum & siliceous ground \\
\hline Xeranthemuт аппиит $\mathrm{L}$ & 3.3 \\
\hline Poa pratensis $\mathrm{L}$. & 2.2 \\
\hline Phlomoides tuberosa (L.) & 1.1 \\
\hline Moench & \\
\hline Achillea millefolium $\mathrm{L}$. & 1.1 \\
\hline Vicia cracca $\mathrm{L}$. & 1.1 \\
\hline Galium verum $\mathrm{L}$. & 1.1 \\
\hline Onobrychis cyri Grossh & 1.1 \\
\hline Melilotus officinalis (L.) Pall. & 1.1 \\
\hline Anthericum liliago $\mathrm{L}$ & 1.1 \\
\hline Salvia pratensis $\mathrm{L}$. & 1.1 \\
\hline Euphorbia esula L. & 1.1 \\
\hline Tragopogon dubius Scop. & 1.1 \\
\hline Triticum durum Desf. & 1.1 \\
\hline Plantago media $\mathrm{L}$. & 1.1 \\
\hline Plantago lanceolata $\mathrm{L}$. & 1.1 \\
\hline Eryngium campestre L. & 1.1 \\
\hline Securigea varia (L.) Lassen & 1.1 \\
\hline Cichorium intybus $\mathrm{L}$ & 1.1 \\
\hline Galium aparine $\mathrm{L}$. & 1.1 \\
\hline $\begin{array}{l}\text { Arrhenatherum elatius (L.) P. } \\
\text { Beauv. ex J. Presl \& C. Presl. }\end{array}$ & 1.1 \\
\hline Ulmus carpinifolia Gled & + \\
\hline Pyrus amygdaliformis Vill & + \\
\hline
\end{tabular}


The Phlomoides tuberosa is a perennial plant with a well developed cylindrical rhizome and small roots with partly thickened tubers. The grass cutting continuously performed on the meadow where the species was reported should not cause the reduction of its number or the species extinction. Since it is identified in few localities, adequate measures should be certainly undertaken to prevent the decrease in number of the species or the extinction of the present habitats. The species in Serbia is protected by the Law on Nature Protection (Official gazette of RS", no. 5/2010 and 47/2011), which means that the trade and use are monitored according to special regulatory standards.

\section{CONCLUSION}

New chorological data from Kosovo and Metohija North on the European endemic species Gladiolus palustris Gaud. May largely contribute to the evaluation of the degree of endangerment of the species population and the possible application of protection measures in order to prevent destruction and change of the habitats of this species. The new two localities of species Himantoglossum caprinum (M. Bieb.) Spreng.on the territory of Kosovo and Metohija could explain the area of this type in the flora of Serbia, which will enable proper protection of this species. The localities on Rogozna Mt. represent new and so far unknown localities for the Narcissus poeticus subsp. radiiflorus (Salisb.) Baker species and may serve as a good data on the chorology of this species in the Flora of Serbia and offer a good basis for proposing preventive and protective measures and actions. Since there were only few records of Phlomodes tuberosa in Serbia, new finding in the Ibar valley present second locality for Kosovo territory and important contribution to the chorology of this very rare plant in Serbian flora.

The familiarity with the distribution of the mentioned species, the conditions of their habitats and potentionally threatening factors would present a good foundation for the protection of these plants, which may secure their survival in Serbia.

\section{REFERENCES}

Bilz, M. 2011. Gladiolus palustris. The IUCN Red List of Threatened Species, pp. 162188-162188.

doi:10.2305/IUCN.UK.2011-1.RLTS.T162188A5555329.en

Bogosavljević, S., Zlatković, B., \& Ranđelović, V. 2007. Flora klisure Svrljiškog Timoka. In: 9th Symposium of Flora of Southeastern Serbia and Neighbouring Regions. Niš (Serbia) September 01-03. Proceeding, pp. 41-54.

Chadburn, H. 2014. Narcissus poeticus. The IUCN Red List of Threatened Species, p. 193504.

doi:10.2305/IUCN.UK.20141.RLTS.T193504A2239955.en

-CITES Secretariat. 2011. Convention on International Trade in Endangered Species of Wild Fauna and Flora. Retrieved from http://www.cites.org/.
-IUCN. 2017. The IUCN Red List of Threatened Species. Version 2017-2. Retrieved from http://www.iucnrelist.org

Jakovljević, K., Lakušić, D., Vukojičić, S., Tomović, G., ŠinžarSekulić, J., \& Stevanović, V. 2011. Richness and diversity of Pontic flora on serpentine of Serbia. Central European Journal of Biology, 6(2), pp. 260-274. doi:10.2478/s11535010-0110-5

Josifović, M. (Ed.). 1974. Flora SR Srbije VI. In. Beograd: Srpska Akademija Nauka i Umetnosti - Odeljenje prirodnomatematičkih nauka.

Josifović, M. (Ed.). 1975. Flora SR Srbije VII. Beograd: Srpska Akademija Nauka i Umetnosti - Odeljenje prirodnomatematičkih nauka.

Josifović, M. (Ed.). 1976. Flora SR Srbije VIII. Beograd: Srpska Akademija Nauka i Umetnosti - Odeljenje prirodnomatematičkih nauka.

Käsermann, C., \& Moser, D.M. 1999. Fiches practiques pour la conservation-Plantes à fleurs et fougères (situation octobre 1999). Berne: Edité par l'Office federal de l'environnement, des fórets et du paysage (OFEFP).

Lampinen, R. 2001. Universal Transverse Mercator (UTM) and Military grid Reference System (MGRS). Retrieved from http://www.luomus.fi/english/botany/afe/map/utm.htm.

Mijović, A., Sekulić, N., Lazarević, P., Stojanović, V., \& Mišić, D. 2012. Biodiverzitet Srbije - stanje i perspektive. Beograd: Zavod za zaštitu prirode Srbije.

Molnár, V.A., Kreutz, K., Óvári, M., Sennikov, A., Bateman, R., Takács, A., Somlyay, L., \& Sramkó, G. 2012. Himantoglossum jankae (Orchidaceae: Orchideae), a new name for a long-misnamed lizard orchid. Phytotaxa 73, pp. 8-12. DOI: http://dx.doi.org/10.11646/phytotaxa.73.1.2

Službeni glasnik RS 2010. Pravilnik o proglašenju i zaštiti strogo zaštićenih i zaštićenih divljih vrsta biljaka, životinja i gljiva. Službeni glasnik RS, br. 05/2010 i 47/2011.

Rankou, H. 2011. Himantoglossum caprinum. The IUCN Red List of Threatened Species, p. 162090.

Salmaki, Y., Zarre, S., \& Heubl, G. 2012. The genus Phlomoides Moench (Lamiaceae; Lamioideae; Phlomideae) in Iran: An updated synopsis. Iran J. Bot., 18(2), pp. 207-220.

Salmaki, Y., \& Jonarchi, M.R. 2014. Phlomoides binaludensis (Phlomoideae, Lamioideae, Lamiaceae), a new species from northeastern Iran. Phytotaxa, 172(3), pp. 265-270. doi:10.11646/phytotaxa.172.3.7

Sarić, M.R. (Ed.). 1986. Flora SR Srbije X. Beograd: Srpska Akademija Nauka i Umetnosti - Odeljenje prirodnomatematičkih nauka.

Stevanović, V., Vasić, V. (Eds.). 1995. Biodiverzitet Jugoslavije sa pregledom vrsta od međunarodnog značaja. Beograd: Biološki fakultet / Ecolibri.

Stevanović, V. (Ed.). 1999. Iščezli i krajnje ugroženi taksoni. In Crvena knjiga flore Srbije. 1. Beograd: Ministarstvo za životnu sredinu Republike Srbije / Biloški fakultet / Zavod za zaštitu prirode Republike Srbije.

Stojanović, V., Rilak, S., Jelić, I., Perić, R., Saboljević, M., \& Lazarević, P. 2015. Biljke od međunarodnog značaja u flori Srbije. Beograd: Zavod za zaštitu prirode Srbije.

The Plant List, Version 1. 12 2013. Retrieved from http://www.theplantlist.org/. 
Tomić-Stanković, K. 1967. Prilog poznavanju flore Ibarskog Kolašina. Zbornik Filozofskog fakulteta u Prištini, 4, pp. 6983. B.

Tomović, G. 2007. Fitogeografska pripadnost, distribucija i centri diverziteta balkanske endemične flore u Srbiji. Univerzitet u Beogradu - Biološki fakultet. Doktorska disertacija.
Tutin, T.G., Heywood, V.H., Burges, N.A., Moore, D.M., Valentine, D.H., Walters, S.M., Webb, D.A. (Eds.).1972. Flora Europaea 3. Cambridge: University Press.

Tutin, T.G., Heywood, V.H., Burges, N.A., Moore, D.M., Valentine, D.H., Walters, S.M., Webb, D.A. (Eds.).1980. Flora Europaea 5. Cambridge: University Press.

-WCSP (2017). World Checklist of Selected Plant Families, Facilitated by the Royal Botanic Gardens, Kew. Retrieved from http://wcsp.science.kew.org. 